\title{
キクの電照栽培における最適な電照の長さおよび照射時間帯
}

\author{
白山竜次 ${ }^{*} \cdot$ 木戸君枝 \\ 鹿児島県農業開発総合センター花き部 891-0513＼cjkstart鹿児島県指宿市山川岡児ヶ水
}

\section{Effective Night-break Timing and Duration of Optimal Inhibition of Floral Initiation in Chrysanthemum}

\author{
Ryuji Hakuzan* and Kimie Kido \\ Kagoshima Prefectural Institute for Agricultural Development, Flower Division, Ibusuki, Kagoshima 891-0513
}

\begin{abstract}
To establish an effective night-break (NB) lighting system for the commercial production of chrysanthemum, it is necessary to clarify the optimum timing and duration of lighting at night. Therefore, we determined the duration of darkness before the achievement of maximum sensitivity to NB (dusk-NBmax) and the relationship between the timing and duration of light exposure that optimized the inhibition of flowering in the chrysanthemum cultivars 'Jimba' and 'Iwano-hakusen'. The duration of dusk-NBmax was $10 \mathrm{~h}$ and 15-25 min and 7.5-8 h for 'Jimba' and 'Iwano-hakusen', respectively. In both cultivars, the most effective NB timing was achieved by extending the illumination by $0.5-1 \mathrm{~h}$ after the end of NBmax. The inhibitory effects of NB on flowering increased in proportion to the length of NB; however, further extension of NB adversely reduced its effects. The reduction in the NB effect induced by extending the duration of illumination was associated with the presence or absence of darkness before NB. On the basis of these results, we propose a practical lighting system for the optimum inhibition of flowering in chrysanthemum, whereby the most effective timing and duration of NB are $4 \mathrm{~h}$ after dusk and $0.5-1 \mathrm{~h}$ after dusk-Nbmax, respectively, for each cultivar.
\end{abstract}

Key Words : autumn-floweing chrysanthemum, flowering, LED light, summer-to-autumn flowering chrysanthemum キーワード : 秋ギク，LED 電球，花成，夏秋ギク

\section{緒言}

キクは短日植物で，電照による長日処理を行うことによ り，人為的に花芽分化を抑制して開花時期の調整や草丈の 確保を行っている. 産地では限界日長の異なる品種を用い て周年生産を可能にしており, 電照栽培はキクの周年生産 体系を支える基盤技術となっている.

キクに执いて花芽分化抑制効果の高い電照を行らために は, 電照用光源の光質や光量, 点灯する時間帯などに考慮 する必要がある. しかし, 既に設置された光源では, 光質 や光量の変更は容易ではない. そのため設置済みの光源 で，より効果的な電照を行うためには，どの時間帯にどれ くらいの長さで電照するかを検討することが必要になる.

キクの開花制御における電照の時間帯は, これまで暗期 の中心が最も効果が高いとされてきた（船越，1989; 小西 ら, 1990; Machin・Scopes, 1978; リュンガー, 1978; 米村,

2016 年 8 月 25 日 受付. 2016 年 12 月 26 日 受理. 本報告の一部は園芸学会平成 28 年度秋季大会で発表した. 本 研究の一部は農研機構生物系特定産業技術研究支援センター 「攻めの農林水産業の実現に向列革新的技術展開事業（うち 産学の英知を結集した革新的な技術体系の確立)」で実施した.

* Corresponding author. E-mail: hakuzan@pref.kagoshima.lg.jp
1993）。しし，白山・郡山（2013）は，花芽分化抑制効果 の高い電照時間帯（Night Break max 以下 NBmax と略す） は暗期の中心ではなく，暗期開始から暗期中断開始までの 経過時間（Dusk-NB）が関与していることを明らかにした. さらに, 白山・郡山（2014）は夏秋ギクおよび秋ギク数品 種を用いて，暗期開始から効果の高い電照時間帯までの時 間（Dusk-NBmax）は個々の品種の限界暗期長と連動して いることを明らかにした。

しかし，白山・郡山（2013，2014）の結果は，短時間の 電照実験から得られたものであり，実際に生産現場で行わ れている $3 \sim 5$ 時間の電照において, NBmax を考慮しなが ら，どの時間帯に電照すればよいかという点についての十 分な検討は行われていない.

一方, 電照の効果は電照の長さで変化する, すなわち量 的な反応を示すことが知られており，一般的に電照の効果 は光の放射照度と照射時間の積に比例すると考えられてい る（樋口，1993；リュンガー, 1978; 佐々木ら，2013）. 従っ て光源の照度が低く，花芽分化抑制効果に不安がある場合 は，電照時間を延長することで必要な花芽分化抑制効果が 得られるとされている（小西ら，1990; 坂場, 2011; 米村, 1993).

しかし，必ずしも電照時間を延長することで電照効果が 
最大化するわけではなく, Cathey・Borthwick（1970）は蛍 光灯による終夜の間欠照明で花芽分化抑制効果が低下寸る ことを報告し，また終夜照明が 18 時間日長に比較して花 芽分化抑制効果が低下寸るよらな結果が夏秋ギク “岩の白 扇’や'フローラル優香’ で得られている (白山, 未発表). このように, 電照時間の長さと花芽分化抑制効果の関係に ついては, 未解明の部分が多い。

そこで本報では, 白山・郡山（2014）が示した DuskNBmax の考方方に基づいて, 実用的な電照時間帯と花芽 分化抑制効果の関係について検討するとともに, 電照の長 さと花芽分化抑制効果の関係について検討を行い, キクに 抢ける花芽分化抑制効果の高い電照方法とその考方方につ いて明らかにしょらとした。な拈，本研究は長寿命で省エ ネ効果の高い光源として, キク電照栽培用への普及が期待 されている赤色（以下 R 光）LEDを用いて実施した.

\section{材料および方法}

\section{1. 共通の実験方法}

実験は鹿児島県農業開発総合センタ一花き部（指宿市） の硬質プラスチックハウスで行った. 電照用の光源は, 消 費電力 $6.5 \mathrm{~W}$ ，ピーク波長 $630 \mathrm{~nm}$ の R光 LED (AG10ASR0362E26，(株）エルム）を実験 $1 ， 4 ， 5$ 抢よび 6 に，消費電力 $6 \mathrm{~W}$ ピーク波長 $644 \mathrm{~nm}$ 赤色 LED（AG-R250，(株) エルム） を実験 2,3 亿使用した。光源の波長特性を第 1 図に示し た. 各光源の放射照度の測定は, $400 \sim 1,050 \mathrm{~nm}$ の波長域 に感度を持つプローブ（LP471RAD，Delta OHM S.r.L.）を 装着した放射照度計（HD2102.2，Delta OHM S.r.L.）を用 いて行った。電照時間の制御には, 1 分単位で設定可能な デジタル式電照タイマー（TBC231，パナソニック(株)） を使用した，処理区の間は，区間での光の干渉を防ぐため に, 遮へい幕（ホワイトシルバー, 東罐興産(株)）で仕 切った. 光源の畧面からの高さは，実験で異なり $1.5 〜$ $1.8 \mathrm{~m}$ の範囲で設定した。 暗期時間はシェードを用いて 18:00〜 6:00の 12 時間とした. 供試した種苗は, 採穂日

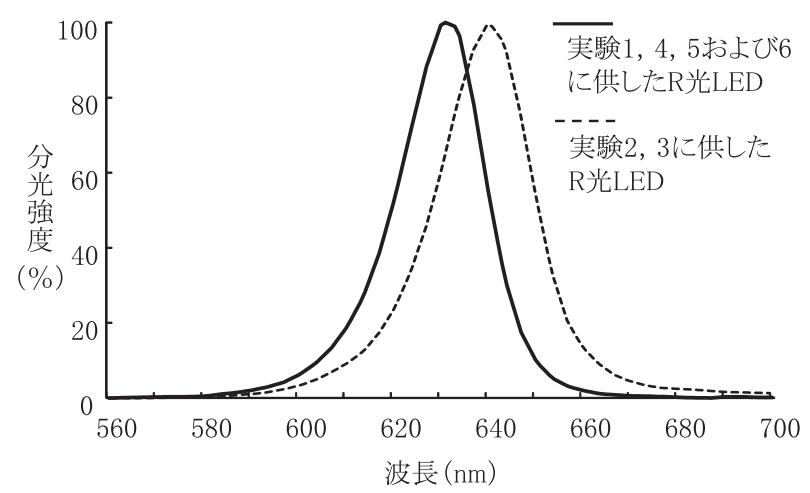

第 1 図 実験に供試した $\mathrm{R}$ 光 $\mathrm{LED}$ 電球の波長特性 分光強度はピーク波長の放射照度を 100 とした場合の 各波長ごとの割合を示す 測定機材 : 英弘精機(株) 分光放射照度計, MS-720
や冷蔵期間の揃った発根苗を使用した。栽植様式は床幅 $90 \mathrm{~cm}$ の平畧に $15 \mathrm{~cm} \cdot 6$ 目ネットを用いて，外側 2 列に 1 目当たり 2 本植光，中央 2 列に植付けなし（2-2-0-0-2-2）と した. 無摘心栽培とし, 施肥は $\mathrm{N}: \mathrm{P}_{2} \mathrm{O}_{5}: \mathrm{K}_{2} \mathrm{O}=1.2: 0.8: 0.8$ $\mathrm{kg} \cdot \mathrm{a}^{-1}$ で，全量基肥施用とした．定植後の初期生育を揃 えるために, 全区で 9 日間, 通常の電照 $(22: 00 \sim 3: 00)$ を行ったのち，10日目から処理を開始した，温度管理は， 無加温とし, 昼間は $25^{\circ} \mathrm{C} て ゙$ 換気した.

\section{2. 秋ギク ‘神馬’ における花芽分化抑制効果の高い電照 時間帯 \\ 1）“神馬’の電照における暗期開始からの経過時間と花芽 分化抑制効果 (実験 1)}

シェードを用いた 18:00〜 6:00 の暗黒条件下（12 時間 暗期）に和忷る電照の効果が，照射する時間帯でどのよう に変化するかを検討した．電照開始の時刻は 19:00（暗期 長 (以下同じ) : 1 時間)，21:00 (3 時間), 23:00 (5 時間), $0: 00$ (6 時間)， $1: 00$ (7 時間)，2:00 (8 時間)， $3: 00$ (9 時 間), $4: 00$ (10 時間), $4: 15$ (10 時間 15 分), $4: 30$ (10 時間 30 分)，4:45 (10 時間 45 分)，5:00 (11 時間) および 5:15 (11 時間 15 分）で，点灯時間は各 10 分とした。畧面に抒 けるR 光 LED の放射照度は $154 \sim 167 \mathrm{~mW} ・ \mathrm{~m}^{-2}$ とした. 定植は 2015 年 8 月 19 日に行い, 各区 75 89 株を供試し た．処理は全区の発蕾が完了するまで継続した．

\section{2） ‘神馬’における NBmax 付近の電照の時間帯と花芽分 化抑制効果 (実験 2)}

シェードを用いた 18:00〜 6:00の暗黒条件下（12 時間 暗期）に和敌る中夜〜後夜半の時間帯の異なる $1 \sim 3$ 時 間の電照が ‘神馬’の花芽分化までの展開葉数にごのよう な影響を及ぼすかを調査した．白山・郡山（2014）の暗期 中断時間を40 分とした実験では，“神馬’の Dusk-NBmax は9〜10.5 時間とされており, 暗期開始時刻を $18: 00$ とし た場合, 3:00〜 4:30 と想定される. そこで, 電照時間帯を $23: 00 \sim 2: 00$ (暗期長（以下同じ）: 5 時間)， $0: 00 \sim 3: 00$ (6時間), $1: 00 \sim 4: 00$ (7 時間), $2: 00 \sim 5: 00$ (8 時間) 特 よび $3: 00 \sim 6: 00$ (9 時間) の 5 区（以上， 3 時間電照）に, $4: 00 \sim 6: 00$ （暗期長 10 時間， 2 時間電照）および $5: 00 〜$ $6: 00$ （暗期長 11 時間， 1 時間電照）を加えて 7 区とした. “神馬’ は電照汶対する感度が高く，通常の電照方法では 処理期間中に発蕾しない可能性が想定されたため, 光量の 低いLED（畧面に打汀る R 光 LED の放射照度は41〜 $44 \mathrm{~mW} \cdot \mathrm{m}^{-2}$ )を使用し，さらに定植 26 日目からすべての 区を 1 日拈きの隔日電照に切り替えた。定植は 2015 年 8 月 17 日に行い, 各区 $78 \sim 80$ 株を供試した. 処理は調査 終了時（定植 69 日後）まで継続した.

3）“神馬’における電照時間の長さと花芽分化抑制効果 (実験 3)

シェードを用いた 18:00〜 6:00の暗黒条件下（12 時間 暗期）に打ける電照の長さが ‘神馬” の花芽分化までの展 開葉数にどのような影響を及ぼすかを調査した。暗期開始 
10 時間後の 4:00を電照の終了時刻として, 電照時間帯を $3: 00 \sim 4: 00$ (電照時間（以下同じ）: 1 時間), $2: 00 \sim 4: 00$ (2 時間), $1: 00 \sim 4: 00$ (3 時間), $0: 00 \sim 4: 00$ (4 時 間), $22: 00 \sim 4: 00$ (6 時間), 20:00〜4:00（8時間）扎よび $18: 00 \sim 4: 00$ (10 時間) の 7 区を設置した. 実験 2 と同様 に “神馬” は電照に対する感度が高く, 処理期間中に発蕾 しない可能性が考兄られるため, 畧面に颃ける R光 LED の放射照度は $40 \sim 45 \mathrm{~mW} \cdot \mathrm{m}^{-2}$ として, 定植 26 日目から すべての区を1日报きの隔日電照に切り替えた。定植は 2015 年 8 月 17 日に行い, 各区 $76 \sim 82$ 株を供試した. 処 理は調査終了時（定植69日）まで継続した。

\section{3. 夏秋ギク “岩の白扇’ における花芽分化抑制効果の高 い電照時間帯}

1） ‘岩の白扇’ の電照における暗期開始からの経過時間と 花芽分化抑制効果（実験 4)

シェードを用いた 18:00〜 6:00の暗黒条件下（12時間 暗期）に打ける電照の効果が，照射する時間帯でどのよう に変化するかを検討した。電照開始の時間は 19:00（暗期 長 (以下同じ) : 1 時間), 20:00 (2 時間), 21:00 (3 時間), $22: 00$ (4 時 間), 23:00 (5 時間), 0:00 (6 時間), $0: 30$ (6 時間 30 分), $1: 00$ (7 時間), $1: 30$ (7 時間 30 分), $2: 00$ (8 時 間), 2:30 (8 時間 30 分), 3:00 (9 時間), 3:30 (9 時間 30 分）扣よび $4: 00$ (10時間) で，点灯時間は各 30 分とした。畧面に打ける R光 LEDの放射照度は231〜 $272 \mathrm{~mW} \cdot \mathrm{m}^{-2}$ とした. 定植は 2016 年 4 月 26 日に行い, 各 区 $75 \sim 80$ 株を供試した。処理は全区の発蕾が完了するま で継続した.

\section{2） “岩の白扇” における NBmax 付近の効果の高い時間帯 (実験 5)}

“神馬”と同様にシェードを用いた 18:00〜 6:00の暗黒 条件下（12 時間暗期）に打ける中夜〜後夜半の時間帯の 異なる 3 時間電照が ‘岩の白扇’ の花芽分化までの展開葉 数にどのよらな影響を及ぼすかを調査した. 白山・郡山 （2014）の暗期中断時間を 1 時間とした実験では，“岩の白 扇’ の Dusk-NBmax は 6.5〜8.5 時間とされており, 暗期開 始を $18: 00$ とした場合， $0: 30 \sim 2: 30$ と想定される. そこ で，電照時間帯を22:00〜 1:00（暗期長（以下同じ）: 4 時間), $23: 00 \sim 2: 00$ (5 時間), $0: 00 \sim 3: 00$ (6 時間), $1: 00 \sim 4: 00$ (7時間), $2: 00 \sim 5: 00$ (8時間) および $3: 00 〜$ 6:00（9時間）の6区を設置した。畧面における R光 LED の放射照度は $190 \sim 201 \mathrm{~mW} \cdot \mathrm{m}^{-2}$ とした. 定植は 2015 年 5 月 11 日に行い, 各区 $82 \sim 85$ 株を供試した. 処理は全区 が発蕾するまで継続した。

\section{3） ‘岩の白扇’ における電照時間の長さと花芽分化抑制効 果（実験 6)}

“神馬’ と同様にシェードを用いた 18:00〜 6:00の暗黒 条件下（12 時間暗期）に打ける電照の長さが ‘岩の白扇” の花芽分化までの展開葉数にどのような影響を及ぼすかを 調査した. 2:00を電照の終了時刻として，電照時間帯を
$1: 00 \sim 2: 00$ (電照時間 (以下同じ) : 1 時間), $0: 00 \sim 2: 00$ (2 時間), $23: 00 \sim 2: 00$ (3 時間), $22: 00 \sim 2: 00$ (4 時間), $21: 00 \sim 2: 00$ (5 時間), $20: 00 \sim 2: 00$ (6時間), 19:00〜 $2: 00$ (7 時間) および $18: 00 \sim 2: 00$ (8 時間) とする 8 区

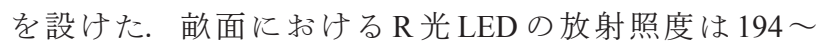
$229 \mathrm{~mW} \cdot \mathrm{m}^{-2}$ とした。定植は 2015 年 5 月 11 日に行い，各 区74〜85 株を供試した。処理は全区が発蕾するまで継続 した.

\section{結 果}

キクに颃いて発蕾率および花芽分化までの展開葉数は花 成反応の指標として用いられている（Thomas・Vince-Prue, 1997)。本報告では様々な電照処理で得られた発蕾率や展 開葉数の差異を電照効果の指標として扱った.

\section{1. 秋ギク ‘神馬’ における花芽分化抑制効果の高い電照 時間帯}

1）“神馬’ の電照における暗期開始からの経過時間と花芽 分化抑制効果 (実験 1)

第 2 図に “神馬” の電照における暗期開始からの経過時 間と展開葉数との関係について示した. 暗期開始 $1 \sim 7$ 時 間区では展開葉数に差が認められなかったが，暗期開始 8 時間から展開葉数が有意に増加し，暗期開始後 10 時間 15 分区で最も展開葉数が多くなった。 その後は，急激に展開 葉数が減少した。

2）“神馬”における NBmax 付近の電照の時間帯と花芽分 化抑制効果（実験 2)

第 3 図に中夜〜後夜半の時間帯の異なる $1 \sim 3$ 時間電照 と “神馬” の花芽分化までの展開葉数および発蕾率につい て示した. 2:00〜 5:00（暗期長 8 時間）区および $3: 00 〜$

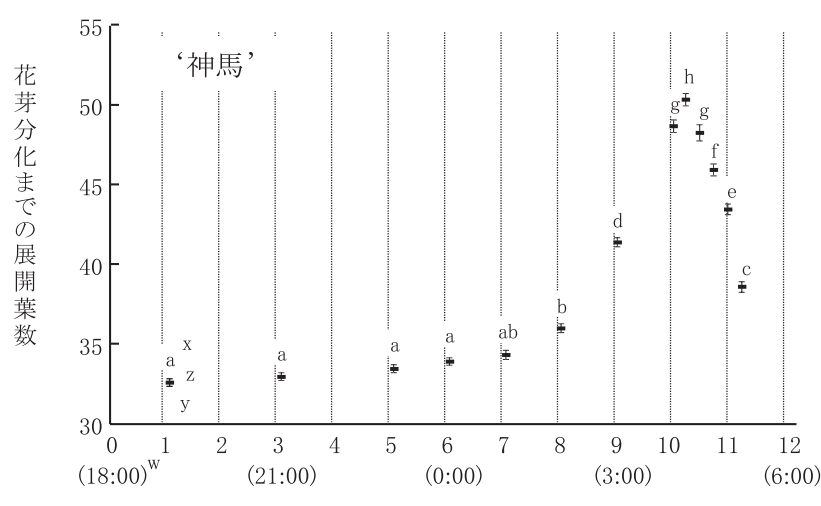

暗期開始功の経過時間 (時刻)

第2 図“神馬’の電照に打ける暗期開始からの経過時間と展 開葉数との関係

電照時間 10 分, 供試光源 $\mathrm{R}$ 光 LED 畧面放射照度 $154 \sim 167 \mathrm{~mW} \cdot \mathrm{m}^{-2}$

暗期は 18:00〜 6:00の 12 時間

z 図中の縦線は標準䛊差を示す $(\mathrm{n}=75 \sim 89)$

y 図中のマーカーの幅は電照の長さを示す（10 分）

x 図中の異なる英文字は Tukey-Kramerの多重検定で有 意差があることを示す $(1 \%)$

w（）内は実際の時刻を表す 


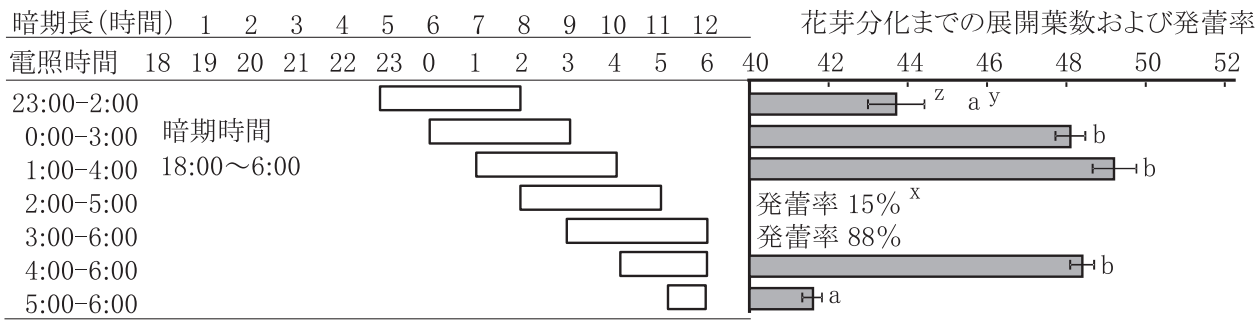

第3図“神馬’における時間帯の異なる電照が花芽分化までの展開葉数に及ぼす影響 z図中のバーは標準詋差を示す（n=78～80)

y 図中の異なる英文字は Tukey-Kramerの多重検定で有意差があることを示す（1\%）

× $2: 00 \sim 5: 00$ 区および 3:00〜 6:00 区は全個体発蕾しなかったため定植 69 日目の発蕾率を調査した

\begin{tabular}{|c|c|c|c|c|c|c|c|c|c|c|c|c|c|c|c|c|c|c|c|c|}
\hline 暗期長 (時間) & ) 1 & 2 & 3 & 4 & 5 & 6 & & & & & 0 & 11 & 12 & & 花芽 & 七ま & 宸 & 㷊数 & よびタ & 発雷率 \\
\hline 電照時間 18 & $\begin{array}{ll}8 & 19 \\
\end{array}$ & 20 & 21 & 22 & 23 & 0 & & & & & 4 & 5 & 6 & 0 & 42 & 44 & 46 & 48 & 50 & 52 \\
\hline $3: 00-4: 00$ & \multirow{7}{*}{$\begin{array}{l}\text { 暗期時一 } \\
18: 00 \text { - }\end{array}$} & & & & & & & & & & & \multirow{7}{*}{\multicolumn{2}{|c|}{$\begin{array}{l}1 \mathrm{~h} \\
2 \mathrm{~h} \\
3 \mathrm{~h} \\
4 \mathrm{~h} \\
6 \mathrm{~h} \\
8 \mathrm{~h} \\
0 \mathrm{~h}\end{array}$}} & \multirow{7}{*}{\multicolumn{3}{|c|}{ 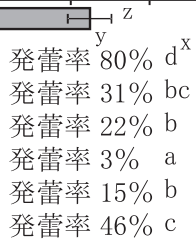 }} & & & & \\
\hline $2: 00-4: 00$ & & 時間 & & & & & & & & & & & & & & & & & & \\
\hline $1: 00-4: 00$ & & & & & & & & & & & & & & & & & & & & \\
\hline $0: 00-4: 00$ & & & & & & & & & & & & & & & & & & & & \\
\hline $22: 00-4: 00$ & & & & & & & & & & & & & & & & & & & & \\
\hline $20: 00-4: 00$ & & & & & & & & & & & & & & & & & & & & \\
\hline $18: 00-4: 00$ L & & & & & & & & & & & & & & & & & & & & \\
\hline
\end{tabular}

第4 図“神馬’に打ける NBmax 付近を終了時刻とした電照の長さが花芽分化までの展開葉数に及ぼす影響 図中のバーは標準誤差を示す $(\mathrm{n}=76 \sim 82)$

y 3:00〜 4:00 区以外は全個体発蕾しなかったため定植 69 日目の発蕾率を調査した

x 図中の異なる英文字は比率の多重比較（Tukey 法）で有意差があることを示す（5\%)

6:00（9時間）区では調査終了時（定植 69 日後）までに発 蕾しない個体があったため, その時点での発蕾率を示し た. $23: 00 \sim 2: 00$ (暗期長 5 時間）区は展開葉数が少な かったが，電照の開始時刻が遅くなるにつれて展開葉数が 増加した. $2: 00 \sim 5: 00$ (暗期長 8 時間）区は発蕾率 15\%, $3: 00 \sim 6: 00$ (9 時間) 区は発蕾率 88\%であった．4:00〜 6:00（暗期長 10 時間）区以降は, 再び展開葉数は減少傾 向に転じた。

\section{3）“神馬’における電照時間の長さと花芽分化抑制効果 (実験 3)}

第4図に4:00を終了時刻とした電照の長さと“神馬” の花芽分化までの展開葉数掞よび発蕾率について示した. 電照時間 $3: 00 \sim 4: 00$ (1 時間) 以外の区は調査終了時（定 植 69 日後）までに発蕾しない個体があったため，その時 点での発蕾率を示した. $3: 00 \sim 4: 00$ (電照時間 1 時間) 区は全個体発蕾したが，2:00〜 4:00（2 時間）区以降は, 電照時間が長くなるにつれて発蕾率が低下し，22:00〜 4:00（6時間）で発蕾率が最も低くなった．20:00〜 4:00 (8 時間) 以降は, 電照時間が長くなるにつれて発蕾率が 高くなった。

\section{2. 夏秋ギク ‘岩の白扇’ における花芽分化抑制効果の高 い電照時間帯}

1） ‘岩の白扇’ の電照における暗期開始からの経過時間と 花芽分化抑制効果 (実験 4)

第 5 図に ‘岩の白扇’ の電照に和ける暗期開始からの経 過時間と展開葉数との関係について示した。暗期開始 1

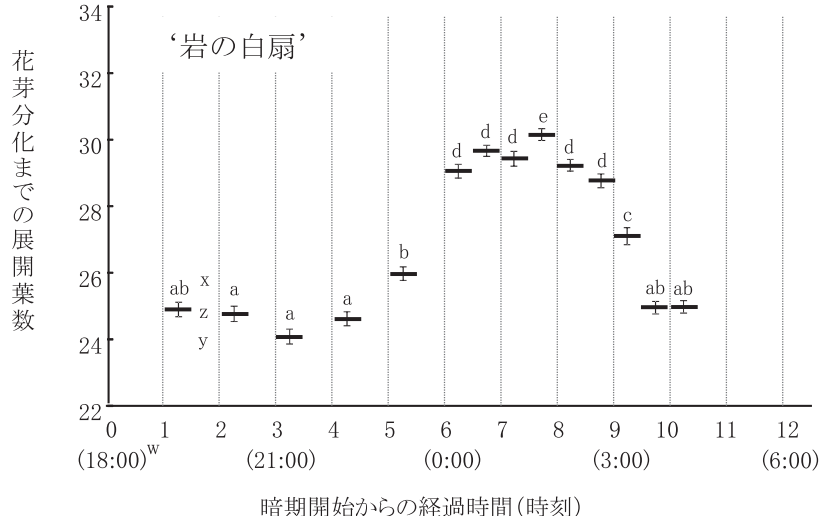

第 5 図 ‘岩の白扇’の電照に打ける暗期開始からの経過時間 と展開葉数との関係

電照時間 30 分，供試光源 R 光 LED 畧面放射照度 $231 \sim 272 \mathrm{~mW} \cdot \mathrm{m}^{-2}$

暗期は $18: 00 \sim 6: 00$ の 12 時間

${ }^{\mathrm{z}}$ 図中の縦線は標準誤差を示す $(\mathrm{n}=75 \sim 80)$

y 図中のマーカーの幅は電照の長さを示す (30 分)

x 図中の異なる英文字はTukey-Kramerの多重検定で有 意差があることを示す $(1 \%)$

w（）内は実際の時刻を表す

4 時間区では展開葉数に差が認められなかったが, 暗期開 始 5 時間から展開葉数が増加し，暗期開始 7 時間 30 分区 で最も展開葉数が多くなった．全区間で比較的展開葉数が 多かったのは，暗期開始 $6 \sim 8$ 時間 30 分であった．暗期 開始 9 時間以降は, 展開葉数が減少した. 




第 6 図 “岩の白扇’に打ける 3 時間の時間帯の異なる電照が花芽分化までの展開葉数に及ぼす影響 z 図中のバーは標準誤差を示す $(\mathrm{n}=82 \sim 85)$

y 図中の異なる英文字は Tukey-Kramerの多重検定で有意差があることを示す（1\%）

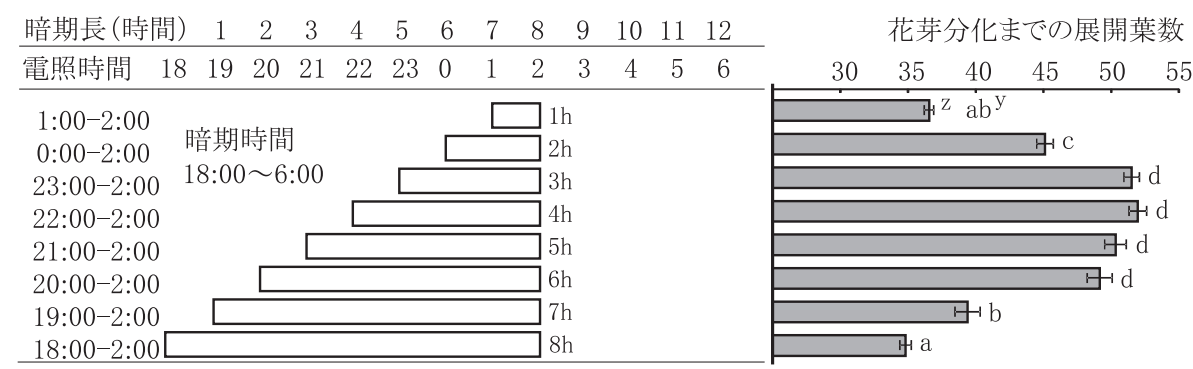

第7図 ‘岩の白扇’ における NBmax 付近を終了時刻とした電照の長さが花芽分化までの展開葉数に及ぼす影響 z 図中のバーは標準䛊差を示す $(\mathrm{n}=74 \sim 85)$

y 図中の異なる英文字は Tukey-Kramerの多重検定で有意差があることを示す（1\%）

\section{2）“岩の白扇’における NBmax 付近の効果の高い時間帯 (実験 5)}

第 6 図に中夜〜後夜半の時間帯の異なる 3 時間電照と “岩の白扇’の花芽分化までの展開葉数との関係について 示した. $22: 00 \sim 1: 00$ (暗期長 4 時間）区は展開葉数が少 なかったが，電照の開始時刻が遅くなるにつれて展開葉数 が増加し，0:00〜3:00（6時間）区で最も多くなった。 そ の後, 再び展開葉数は減少傾向に転じた.

\section{3）‘岩の白扇’における電照時間の長さと花芽分化抑制効 果 (実験 6)}

第7図に2:00を電照の終了時刻とした電照の長さと“岩 の白扇’の花芽分化までの展開葉数の関係について示し た. $1: 00 \sim 2: 00$ (電照時間 1 時間) 区は展開葉数が少な かったが，電照時間が長くなるにつれて展開葉数が増加 し, $23: 00 \sim 2: 00$ (3 時間), 22:00 2:00 (4 時間), 21:00 $2: 00$ (5 時間) おょよび $20: 00 \sim 2: 00$ (6 時間) で最も多く なった。しかし，19:00２:00（7時間）からは急激に減 少した。

\section{考察}

実験 1 の結果から “神馬” の暗期開始から効果の高い電 照時間帯までの時間（Dusk-NBmax）は，電照時間 10 分を 加えると 10 時間 15 分 25 分 (第 2 図) と考兄られる. 白 山・郡山（2014）の電照時間を40 分とした実験に扔いて, ‘神馬’ の Dusk-NBmaxは9〜10.5 時間とされている. 本 実験の結果は，白山・郡山（2014）の結果と矛盾せず，本 実験により Dusk-NBmax の範囲をより絞り込むことができ
た。 そこで，実験 2 と捻いて，暗期長を $5 \sim 11$ 時間とする $1 \sim 3$ 時間の電照の効果を比較した結果，Dusk-NBmaxを 含屯暗期長 8 時間の 3 時間電照で最も高い花芽分化抑制 効果が得られた（第3図）。一方，“岩の白扇’の DuskNBmax は，電照時間 30 分を加えると $7.5 \sim 8$ 時間（第 5 図）と考光られる。白山・郡山（2014）の電照時間を 1 時 間とした実験に打いて，“岩の白扇’のDusk-NBmaxは 6.5〜8.5 時間とされている. 本実験の結果は，白山・郡山 （2014）の結果と矛盾せず，本実験により Dusk-NBmaxの 範囲をより絞り込むことができた。そこで，実験 5 亿おい て，暗期長を $4 \sim 9$ 時間とする 3 時間の電照の効果を比較 した。 その結果，Dusk-NBmax を含む暗期長 6 時間の電照 区で最も高い花芽分化抑制効果が得られた（第 6 図）。こ のように ‘神馬’，“岩の白扇’ともに Dusk-NBmax 付近を 含丈，Dusk-NBmax に対して前 $1.5 \sim 2$ 時間，後ろ $0.5 \sim 1$ 時間を電照時間帯とした場合の効果が高かった。 このこと から, 効果の高い Dusk-NBmax 付近の電照方法について は，Dusk-NBmax よりやや後の時間を含んで，前の方に延 長する電照方法の効果が高いと考光られた．Dusk-NBmax が異なる両品種で，効果の高い電照時間帯に同じょうな傾 向が得られたことは，品種によって異なる限界暗期が電照 の効果的な時間帯を判断する指標となり得ること（白山・ 郡山，2013）を裏付けている.

次に “神馬”に颃いて, Dusk-NBmax 付近を終了時刻と する電照時間の長さと花芽分化抑制効果を比較した結果, 電照 6 時間までは効果が高くなったが， 8 および 10 時間で は花芽分化抑制効果が明確に低下した（第 4 図)。一方, 


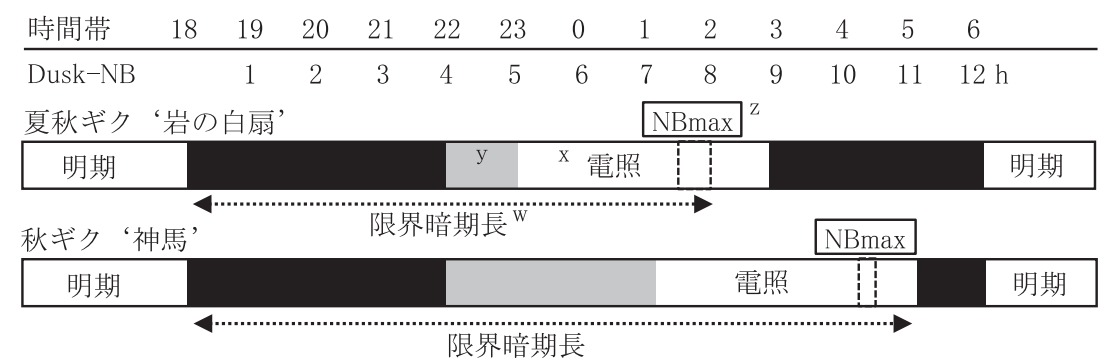

限界暗期長

\begin{abstract}
第 8 図 18 時を暗期開始とした場合の夏秋ギク “岩の白扇’および秋ギク“神馬’に括ける電照効果の高い時間帯の推定 ${ }^{\mathrm{z}} \mathrm{NBmax}$ は最も電照効果の高い時間帯

y 図中央の灰色と白抜き部分の範囲が最も効果が高い電照時間帯を示す

$\mathrm{x}$ 図中央の白抜き部分は慣行の 4 時間電照の場合の効果が高い電照時間帯を示す

w 限界暗期長は白山・郡山（2014）の結果より推定
\end{abstract}

“岩の白扇’の Dusk-NBmax 付近を終了時刻とする電照時 間の長さと花芽分化抑制効果を比較した結果，3〜 6時間 の電照で効果はピークに達し，それ以上は効果が低下寸る など“神馬”と同じょうな傾向を示した（第7図）。なお，


4:00区では同一日植付けで同一処理時間であるにもかか わらず，電照の効果に差が生じた，両区に打ける電照の放 射照度に差がないことや実験 2 と 3 をハウスの南北に分け て試験区を設置したことなどから，両区の差には実験 2 と 3 に打ける施設内の環境条件の違いなどが影響を及ぼした 可能性が考兄られる.

電照の時間については，これまで電照する時間が長いほ ぞ花芽分化抑制効果が高くなると考兄られて扣り，電照の 光量が不足する場合は電照時間を長くすることで効果を補 ら方法が提案されてきた。しかし，本実験結果から，ある 一定時間以上電照時間を長くすると逆に花芽分化抑制効果 が低下寸る現象が認められた。電照時間は長い方が効果が 高いとされる従来の考方澷は，効果が最大になる限界の 長さがあり，それ以上の時間ではむしろ効果が低下するこ とが明らかとなった。

長時間電照による花芽分化抑制効果の低下の理由を考兄 る場合，電照時間の影響よりも，明期終了から電照開始ま での暗期の長さが電照効果に関与している可能性が考兄ら れる。すなわち，実験 3 拈よび 6 に打いて長時間電照の花 芽分化抑制効果が低下したのは，電照の長さの影響より も，長時間電照により明期終了から電照開始までの暗期の 長さが短くなったことに起因する可能性が考兄られる。 Cathey・Borthwick（1970）は，蛍光灯による間欠電照を終 夜実施するとキクの花芽分化抑制効果が低下寸ることを確 認したらえで，暗期開始から 4 時間の暗期時間を確保する ことにより，その後の電照の効果が高くなることを報告し ている。これらの結果は, キクの効果的な電照には, 暗期 開始後に一定時間の連続した暗期が必要であることを示し ている.

高い電照効果を得るために，電照前に一定時間の暗期が 必要である要因については明らかでない. Cathey・Borthwick
（1970）は，フィトクロムの活性型であるPfr に着目し，効 果的な電照には，明期終了時に存在するPfr の量がその後 低下し，電照により再び増加することが必要であるとして いる. しかしなぜ暗期開始後のPfr の低下が暗期中断のレ スポンスに関与しているかは言及していない，短日植物の 暗期中断による花成抑制には，フィトクロム分子種のひと つである phyBが関与していると考光られている（Ishikawa ら，2005; 長谷，2001）。暗期開始時において phyBは暗反転 （dark reversion）によりPfrからPr 亿変化するが，Pfrがあ る閾値まで低下した時点で，植物は暗期と認識し，ある種 の時間を測定する反応過程（時計機構）が進行し始める （瀧本，1998）と考光られている。キクにおいて暗期開始時 のPfrがある閾值まで低下寸る時間は明らかでないが， ト ウモロコシを使った実験ではP Pr の半減期は 2 時間（古谷, 1976）であるとされている，これらの知見を本実験の結果 と照らし合わせると，フィトクロムの暗反転による明期か ら暗期への転換信号の発信およびそれに伴ら時計機構の開 始を，明期終了後の早い時間帯に打阷電照が妨げること が，レスポンス低下の一因である可能性が示唆される。そ のため，暗期開始後の暗期時間が短い場合は，十分な（こ こでは 4 時間）暗期を確保した場合に比較して，暗期中断 の効果が低下すると考学られる。一方，キクの日長反応に 特忊る開花制御には開花促進物質（フロリゲン）特よび開 花抑制物質（アンチフロリゲン）が大きく関わっており， 両物質のバランスにより開花が制御されることが知られて いる(Higuchi ら，2013; Oda ら，2012）。本実験で得られた 電照効果の高い時間と時間帯，中でも暗期中断前に一定の 暗期が必要といら推論と, これらの遺伝子の発現量の関係 についての解析が望まれる。また，実験 3，6での暗期を なしにした明期延長の場合でも，電照の効果が低下してい ることから，暗期の必要性については，電照の光量と電照 による概日リズムの位相変化などを含めたさらなる研究が 望まれる。

本実験から得られた知見をもとに推定された，夏秋ギク および秋ギクに打ける実用的な効果の高い電照時間帯の構 成を第 8 図に示した。電照が有効なのは，暗期開始から 
Dusk-NBmax $+0.5 \sim 1$ 時間程度までの時間帯である. その らち暗期開始から概ね 4 時間を暗黒として, 暗期開始 4 時 間後から Dusk-NBmax $+0.5 〜 1$ 時間程度までを電照による 明期として構成することで，概ね実用的で効果の高い花芽 分化抑制効果が得られると考えられる.

本研究は現在キク電照用光源として普及しつつある蛍光 灯やLED電球を想定して，R光による電照の開花制御技 術を検討した。一般的な蛍光灯 (昼光色, 昼白色, 電球 色）や赤色蛍光灯および白色 LED は, FR光をほとんど 含んでいないため, 本実験で供試した R 光 LED による実 験結果と注湆同等の結果が得られることが想定される。一 方，白熱電球などの $\mathrm{R}$ 光と FR 光を含む光源の場合は， R 光と異なる反応を生じることが知られている（Thomas・ Vince-Prue, 1997）ため，本試験の結果と異なる反応を示す 可能性が考えられる.

これまでキクの生産現場では, 電照の効果が不十分な場 合に，電照時間を延長することで，電照の効果を高められ るとしてきた。しかし，電照時間を延長することにより， 暗期開始から電照開始までの時間が短くなると，逆に電照 の効果が低下することに十分注意する必要がある.

\section{摘 要}

キクに打ける効果的な電照栽培技術を確立するために は，どの時間帯にどれぐらいの長さで光照射を行えば最も 効果が高いかについて明らかにする必要がある。そこで, 暗期開始から効果の高い電照時間帯までの時間（DuskNBmax)，電照時間帯および電照の長さと花芽分化抑制 効果の関係を秋ギク ‘神馬’ 括よび夏秋ギク ‘岩の白扇’ を用いて検討した。 ‘神馬’执よび“岩の白扇’の DuskNBmax は，それぞれ 10 時間 15〜25 分および 7.5〜8 時間 であった，電照の時間帯は，両品種ともに， Dusk-NBmax の $0.5 〜 1$ 時間後を終点として前に延長する方法が効果が 高かった．電照の長さは，両品種ともに，電照時間を長く すると効果が高くなったが，一定時間以上長くすると逆に 効果が低下した。長時間電照による効果の低下について は，明期終了から電照開始までの暗期の有無が関与してい る可能性が考えられた. 以上の結果をらまえて, 実用的に 花芽分化抑制効果の高い電照時間帯は，秋ギク ‘神馬” お よび夏秋ギク ‘岩の白扇’ ともに概ね暗期開始 4 時間後か ら, 品種固有の Dusk-NBmax $+0.5 \sim 1$ 時間までの範囲であ ることを提示した。

謝 辞 本原稿を投稿するに当たり, ご助言, ご指導いた だいた香川大学農学部深井誠一教授に感謝申し上げます。

\section{引用文献}

Cathey, H. M. and H. A. Borthwick. 1970. Photoreactions controlling flowering of Chrysanthemum morifolium (Ramat. and Hemfl.) illuminated with fluorescent lamps. Plant Physiol. 45: 235-239.
船越圭市. 1989. 開花調節技術. p. 28-38. 船越圭市編著. 切り花栽培の新技術. 改訂キク上巻. 誠文堂新光社. 東京.

古谷雅樹. 1976. フィトクロム．p. 144-174. 岩波書店. 東京.

白山竜次・郡山啓作．2013．キクの電照栽培における暗期 中断電照時間帯が花芽分化抑制に及ぼす影響. 園学 研. 12: 427-432.

白山竜次・郡山啓作。2014. キクに打ける限界日長と花芽 分化抑制に効果の高い暗期中断の時間帯との関係. 園 学研. 13: 357-363.

樋口春三. 1993. 光周性. p. 23-27. 農業技術大系花卉編 1. 生長・開花とその調節. 農文協. 東京.

Higuchi, Y., T. Narumi, A. Oda, Y. Nakano, K. Sumitomo, S. Fukai and T. Hisamatsu. 2013. The gated induction system of a systemic floral inhibitor, antiflorigen, determines obligate short-day flowering in chrysanthemums. Proc. Natl. Acad. Sci. USA 110: 17137-17142.

Ishikawa, R., S. Tamaki, S. Yokoi, N. Inagaki, T. Shinomura, M. Takano and K. Shimamoto. 2005. Suppression of the floral activator $\mathrm{Hd} 3 \mathrm{a}$ is the principal cause of the night break effect in rice. Plant Cell 17: 3326-3336.

小西国義・今西英雄・五井正憲. 1990. 花卉の開花調節. p. 21-31. 養賢堂. 東京.

Machin, B. and N. Scopes. 1978. Chrysanthemums year-round growing. p. 15-16. Blandford Press, Dorset.

長谷あきら. 2001. フィトクロム研究がたどってきた道. p. 24-38. 和田正三・徳富 哲・長谷あきら・長谷部 光泰編. 細胞工学シリーズ 16 「植物の光センシング」. 秀潤社. 東京.

Oda, A., T. Narumi, T. Li, T. Kando, Y. Higuchi, K. Sumitomo, S. Fukai and T. Hisamatsu. 2012. CsFTL3, a chrysanthemum FLOWERING LOCUS T-like gene, is a key regulator of photoperiodic flowering in chrysanthemums. J. Exp. Bot. 63: $1461-1477$.

リュンガー ワルター。 1978. 園芸植物の開花生理と栽培 (浅平 端 - 中村英司訳). p. 48-50. 誠文堂新光社. 東京.

坂場 功. 2011. 日長管理による開花調節. p. 126-132. 大石一史編著．キクをつくりこなす．農文協．東京．

佐々木 厚・吉村正久・鈴木誠一・森山厳與・金浜耕基. 2013. 赤色電球形蛍光ランプによる暗期中断時間と光 強度がスプレーギクの開花と花房の形状に及ぼす影 響. 園学研. 12: 187-194.

瀧本 敦. 1998. 花を咲かせるものは何か一花成ホルモン を求めて. p. 162-196. 中央公論社. 東京.

Thomas, B. and D. Vince-Prue. 1997. Photoperiodism in plants, 2nd ed. p. 15-18. California Academic Press, San Diego.

米村浩次. 1993. 日長反応と日長による制御. p. 147-154. 農業技術大系花卉編 1 . 生長・開花とその調節。農文 協. 東京. 